\title{
Etika Profesi Auditor dalam Nilai Budaya Tri Hita Karana
}

\author{
Aida Rakhmawati ${ }^{1}$ \\ Fakultas Ekonomi dan Bisnis \\ Universitas Airlangga, Indonesia \\ Email : rakhmawatiaida@gmail.com
}

\begin{abstract}
ABSTRAK
Peneliti mencoba mendiskripsikan nilai-nilai etika profesi dan kode etik profesi akuntansi seorang auditor dilihat dari perspektif Tri Hita Karana. Tri Hita Karana sebagai paradigma sementara literatur dan etik profesi auditor sebagai wawasan penulis kemudian Tri Hita Karana disandingkan dengan kode etik yang berlaku; AAOIFI, AICPA, dan IAI. Kesimpulannya, budaya penting bagi pembangun karakter dan sifat manusia. Nilai-nilai budaya menjembatani perbedaan agama dan budaya, menciptakan masyarakat kooperatif, memberdayakan manusia, menghapuskan kesenjangan antar ras dan golongan, serta mengubah persepsi bahwa hal materil sebagai tujuan utama dalam bekerja.
\end{abstract}

Kata Kunci: $\quad$ Etika; Auditor; Tri Hita Karana.

\section{Accounting Professional Ethics in Tri Hita Karana Cultural Value}

\section{ABSTRACT}

Researcher tries to describe the ethical values of profession and accounting code of ethics of an auditor from the perspective of Tri Hita Karana. Tri Hita Karana used as the paradigm while literature and ethics of profession of auditors as author's insight, Tri Hita Karana paired with prevailing code of ethics; AAOIFI, AICPA, and IAI. In conclusion, culture is important for character builder and human nature, it makes possibilities to open communication across religious and culture, creating cooperative communities, empowering people, eliminating gap between races and groups, and change the perception material things as the sole purpose of working.

Keywords: $\quad$ Ethics; Auditor; Tri Hita Karana.

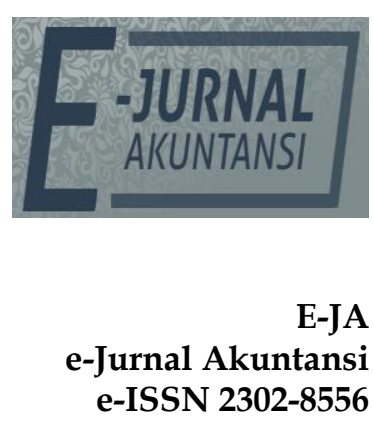

Vol. 30 No. 2

Denpasar, Februari 2020

Hal. 474-489

Artikel Masuk: 24 Oktober 2019

Tanggal Diterima: 6 Februari 2020 


\section{PENDAHULUAN}

Seiring perkembangan zaman, etika pada masa kini merupakan hal yang menarik dan menjadi sorotan. Etika kemudian dihubungkan dengan tindakan etis dan tindakan tidak etis yang dilakukan oleh seseorang. Dalam beberapa tahun terakhir, kasus mengenai terjadinya perilaku tidak etis dari pelaku Profesi di Indonesia semakin marak terjadi. Kasus terkait dengan etik auditor seperti kasus yang mengaitkan Kantor Akuntan Publik (KAP) mitra Ernest \& Young's di Indonesia pada tahun 2017, yaitu KAP Purwantono Suherman \& Surja dianggap melakukan pemberian opini yang dihasilkan berdasarkan bukti audit yang dianggap tidak memadai serta adanya kegiatan audit yang hasilnya tidak berdasarkan data yang akurat. Kemudian ada pula Mulyana W Kusuma yang merupakan anggota KPU pada tahun 2004. Mulyana dianggap melakukan penyuapan kepada Salman Khairiansyah selaku anggota tim auditor BPK, yang bertugas melakukan audit keuangan pengadaan logistik pemilu pada saat itu. Lalu pada tahun 2001 terdapat sembilan KAP yang dianggap melakukan kegiatan kolusi bersama kliennya. Kasus tersebut kemudian diusut oleh pihak kepolisian berdasarkan pantauan dari Indonesian Corruption Watch (ICW) atas laporan dari Badan Pengawas Keuangan dan Pembangunan (BPKP) yang menduga telah terjadi kegiatan kolusi atara KAP yang dimaksud dengan pihak bank yang dilakukan audit pada tahun 1995-1997. BPKP kemudian menemukan bahwa audit yang dilakukan pada kurang lebih 36 bank oleh sembilan dari sepuluh KAP dianggap bermasalah karena tidak dilakukannya pemeriksaan berdasarkan standar audit. Hal tersebut kemudian menyebabkan hasil audit tidak sesuai dengan kenyataan, dimana mayoritas bank yang diaudit teryata merupakan bank-bank yang masuk dalam kategori dibekukan kegiatannya oleh pemerintah. Beberapa kasus tersebut memperlihatkan bentuk nyata pelanggaran etika profesi yang dilakukan oleh auditor. Berkaitan dengan etika, pekerjaan seorang auditor tak bisa terlepas dari peranan etika di dalamnya. Auditor yang berperan sebagai salah satu pelayan publik mempunyai peranan penting dalam memberikan penilaian atas kewajaran dari sebuah laporan keuangan perusahaan ataupun lembaga yang diperiksa. Selain itu, auditor memiliki kewajiban yang berbentuk perjanjian berbentuk kewajiban etis terhadap shareholder, kreditur, pegawai dan juga rekanan ataupun pihak ketiga utuk melakukan kegiatan pemeriksaan pada laporan keuangan. Peranan auditor dikatakan berjalan bila prinsip dasar independensi auditor menjadi dasar dalam pelaksanaan tugasnya.

Hp \& Payamta (2002) dalam penelitiannya mengungkapkan bahwa berdasarkan Pedoman Etika IFAC, syarat-syarat etika dalam suatu organisasi yang menaungi akuntan sebaiknya disusun berdasarkan pada prinsip-prinsip dasar yang mengatur akuntan dalam menjalankan tugasnya secara profesional. Prinsip-prisip tersebut seperti integritas, obyektifitas, keindependensian, kepercayaan, standar-standar teknis, kompetensi, dan perilaku etis.Pada penelitian yang dilakukan oleh Ludigdo \& Kamayanti (2012), mereka mencoba memahami alasan banyaknya akuntan yang melakukan tindakan tidak etis bila dilihat berdasarkan perspektif budaya. Budaya sendiri digunakan sebagai nilai yang dibawa oleh suatu bangsa. Indonesia menganut nilai-nilai yang tercermin pada Pancasila dan begitu pula dengan bangsa lain yang juga mempunyai cerminan nilai sendiri. Adanya budaya serta diaplikasikannya aturan yang 
berlaku, seharusnya dapat mencegah perilaku tidak etis dari akuntan. Keberhasilan kinerja suatu profesi memerlukan jaminan perolehan kebudayaan yang menganut bersama seperangkat nilai dan metode yang digunakan secara konsisten. Nilai-nilai baik yang dianut oleh auditor kemudian membentuk sikap kerja yang baik pula. Hal tersebut tentu nampak pada hasil kinerja yang baik bagi auditor. Menurut Sarita (2009), seorang auditor akan mendapatkan kepuasan pada pekerjaannya karena adanya kontrol internal berupa kemampuan kerja dan juga tindakan kerja sehingga dapat menghasilkan keberhasilan dalam bekerja. Sementara itu, ada pula auditor yang merasa bahwa terdapat kontrol eksternal yang berada diluar dirinya yaitu berupa nasib dan juga keberuntungan serta kekuasaan atasan dan juga lingkungan kerja yang mendukung keberhasilan dari hasil pekerjaan yang dilakukannya. Penelitian dari Saputra (2012) mengemukakan hal mengenai kinerja dan kepuasan internal auditor yang memiliki nilai-nilai Tri Hita Karana, dalam penelitian tersebut menyatakan bahwa nilai-nilai yang ada pada Tri Hita Karana mempunyai kontribusi terhadap penguatan locus of control dari auditor-auditor dan juga peningkatan kinerja serta kepuasan mereka. Hal tersebut menjadi gambaran awal yang penting dan inspiratif, dimana nilai-nilai budaya dan spiritual melekat kuat pada kehidupan kerja serta berkontribusi untuk tetap menjaga keselarasan antara etika profesi dan spiritual di lingkungan kerja.

Tri Hita Karana merupakan istilah yang muncul pertama kali pada 11 Nopember 1966 di Konferensi Daerah 1 Badan Perjuangan Umat Hindu Bali bertempat di Perguruan Dwijendra Denpasar, Bali. Hal yang mendasari diadakannya Konferensi tersebut yaitu adanya kesadaran umat Hindu akan kewajibannya untuk berperan serta pada kegiatan pembangunan bangsa demi terwujudnya masyarakat sejahtera, adil dan makmur sesuai Pancasila. Istilah tersebut kemudian mengalami perkembangan, meluas, lalu selanjutnya memasyarakat. Secara leksikal Tri Hita Karana berarti tiga penyebab kesejahteraan. Tri yang berarti tiga, Hita yang berarti sejahtera, Karana yang berarti penyebab. Pada dasarnya Tri Hita Karana memiliki pengertian tiga hal yang menjadi sebab lahirnya kesejahteraan yang bersumber pada Keharmonisan Hubungan Antara Manusia Dengan Tuhannya (Parahyangan), Keharmonisan Hubungan Antara Manusia Dengan Alam Lingkungannya (Palemahan), dan Keharmonisan Hubungan Antara Manusia dengan sesamanya (Pawongan).

Pada penulisan ilmiah pada artikel ini kebaharuan yang dilakukan adalah adanya beberapa kode etik kode etik profesi akuntansi yang berlaku sebagai dasar profesi akuntansi dalam melaksanakan tugasnya. Kode etik profesi bagi akuntan maupun auditor dianggap penting bila melihat banyak terjadinya pelanggaran yang dilakukan seperti yang disebutkan pada uraian sebelumnya.

Penulisan ini menggunakan perspektif budaya Tri Hita Karanan untuk melandasi interpretasi dan mendapatkan makna kode etik akuntan yang ada dalam diri auditor. Penulis kemudian tertarik untuk melakukan penulisan mengenai bagaimana etika auditor dipandang dari perspektif budaya Tri Hita Karana dengan menggunakan pendekatan antorpologi budaya. Tujuan dari penulisan ilmiah ini yaitu untuk mengetahui bagaimana etika profesi auditor dilihat dari perspektif budaya Tri Hita Karana. 


\section{METODE PENELITIAN}

Penulisan ilmiah ini dilakukan menggunakan pendekatan kualitatif yang bertujuan untuk menjelaskan makna di balik realita sosial yang terjadi. Penggunaan pendekatan kualitatif digunakan agar lebih fleksibel dan sesuai dengan keadaan yang ada di lapangan. Pendekatan yang dilakukan dalam penelitian ini mencoba menjelaskan dan mengungkapkan fenomena yang terjadi pada beberapa individu dan lembaga. Penulisan ini dilakukan pada situasi yang alami sehingga tidak ada batasan dalam memaknai dan memahami fenomena yang dikaji. Paradigma yang digunakan dalam penulisan ini adalah interpretif yang menekankan pada makna atau interpretasi sesorang terhadap sebuah simbol. Paradigma ini menekankan pada ilmu bukan didasarkan pada hukum dan prosedur yang baku, dimana setiap gejala atau persitiwa mungkin mempunyai makna yang berbeda (Muslim, 2018).

Penulisan ini dilakukan menggunakan budaya sebagai media pemaknaan sikap etik dari profesi akuntansi. Nilai budaya yang digunakan sebagai paradigma pemaknaan yaitu Tri Hita Karana yang kemudian disandingkan dengan kode etik aturan profesi di bidang akuntansi yang berlaku. Informasi mengenai Tri Hita Karana dihimpun dari literatur baik buku dan tulisan tulisan ilmiah yang juga membahas mengenai Tri Hita Karana. Penggunaan Tri Hita Karana sebagai paradigma penulisan dilakukan dengan harapan dapat menjadi inspirasi pengadopsian kearifan lokal nusantara dalam pengembangan literatur akuntansi di kalangan akademisi. Hal ini penting guna menempatkan akuntansi dapat sedekat mungkin dengan realita nilai budaya yang dianut masyarakat. Kode etik yang ditampilkan di penulisan ini yaitu antara lain etika profesi menurut AAOIFI, AICPA, dan juga IAI. Keterangan dan hal-hal yang terkait dengan kode etik tersebut diperoleh dari literatur dan juga tulisan tulisan ilmiah yang pernah dilakukan sebelumnya.

\section{HASIL DAN PEMBAHASAN}

Sumber daya manusia dalam akutansi merupakan salah satu aset yang dimiliki oleh suatu perusahaan atau suatu instansi. Pengertian tersebut kemudian mengarahkan pemahaman kita pada paham kapitalisme yang berputar pada uang dan kekayaan material. Semangat kapitalisme tersebut kemudian menimbulkan sikap tamak, rakus, egois, materialistis, memetingkan kepentingan individu maupun kelompok tertentu, serta oportunistik pada seseorang ketika mereka ditempatkan pada sebuah instansi ataupun lembaga (Khairi, 2013). Triwuyono (2012) kemudian menyatakan hal yang sejalan, bahwa akuntansi telah terobsesi pada aspek materi dan mengacuhkan aspek non-materi, demikian pula pada simbol akuntasi (account) yang masih terjebak pada simbol materi.

Simbol materi pada akuntansi memberikan pemahaman bahwa akutansi bersifat materialistik dan juga cenderung mengabaikan nilai-nilai spiritualitas, padahal manusia yang merupakan pelaku akutansi mempunyai dua hal yang penting yaitu material dan spiritual. Munthe (2018) dalam Budiasni, et al. (2019) meyatakan bahwa pada kondisi ini meyiratkan adanya implementasi hukum universal dalam ekonomi mainstream (termasuk akuntansi) mempunyai potensi 
yang kuat dalam menghapuskan nilai-nilai asli daerah (local wisdom) yang ada di masyarakat.

Kondisi materialistik ini perlu diimbangi dengan aspek non-materi dalam perjalanannya. Adanya aturan kode etik profesi yang berlaku dan juga adanya suatu konsep nilai-nilai budaya yang dianut hendaknya tetap ada dalam diri auditor. Menurut Widiastuti, et al. (2015) kesadaran etik serta sikap profesional haruslah dimiliki oleh seorang auditor. Hal tersebut penting, dilihat bahwa profesi auditor memerlukan kepercayaan yang berasal dari masyarakat pada hasil audit yang berkualitas dari auditor. Adanya kesadaran etik yang dimiliki oleh diri seorang auditor tentu akan berpengaruh pada perilaku auditor serta penilaian etis atas keputusan yang diambilnya. Sementara itu Bourdieu (1980) dalam Antonius (2011) menyatakan bahwa spritual capital (modal spiritual) adalah kekuatan, pengaruh, pengertahuan dan keadaan yang tercipta pada saat adanya partisipasi dalam tradisi religius atau suatu keagamaan tertentu. Hal yang sama mengenai spiritual capital juga disamapika oleh Munthe (2018) dalam Budiasni et al. (2019), bahwa akuntansi yag menerapkan modal spiritual maupun menjadikan praktek akuntansi yang mendorong perilaku manusia lebih beragama, bernilai spiritualitas dan beretika dalam kehidupan sosial dan lingkungannya. Adanya pandangan mengenai kesadaraan etik bagi auditor kemudian mempertegas bahwa pentingnya keyakinan yang dimiliki oleh auditor dalam suatu lembaga atau istansi dalam melaksanakan tugas profesinya.

Gambaran umum mengenai Etika Profesi Akuntan dan pengelompokkannya, digambarkan dalam Gambar 1. sebagai berikut.

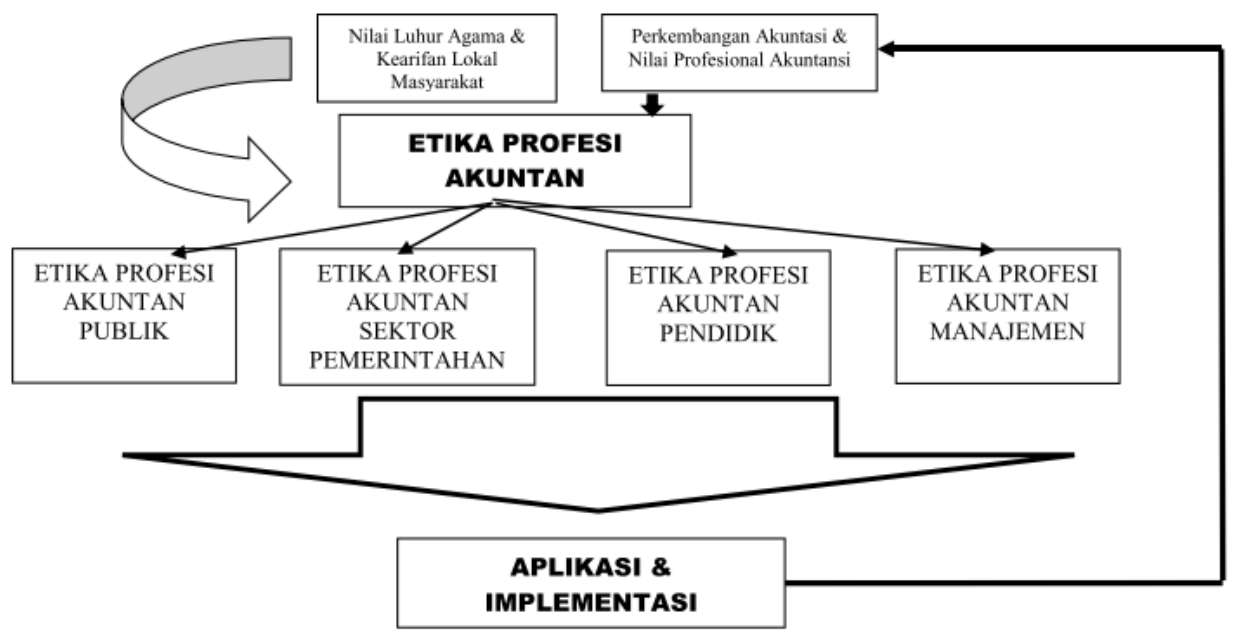

\section{Gambar 1. Gambaran Umum Mengenai Etika Profesi Akuntan Dan Pengelompokkannya}

Sumber : Rosyida, 2017

Secara etimologi, kata Etika berasal dari bahasa Yunani "ethos" (dalam bentuk tunggal) yang memiliki arti adat, kebiasaan, watak, perasaan, cara berpikir sementara "ta etha" (dalam bentuk jamak) yag memiliki arti adat kebiasaan. Filsuf asal Yunani bernama Aristoteles (384-322 SM) telah menggunakan istilah ethos yang kemudian digunakan untuk menjelaskan filsafat moral. Dijelaskan dalam kamus umum Bahasa Indonesia, etika 
merupakan ilmu pengetahuan mengenai azas-azas moral. Sementara itu, dalam Echols \& Shadily (1995) dijelaskan bahwa etika adalah bentuk perilaku etis, layak, memiliki adab dan juga memiliki tatanan susila. Kemudian secara normatif, etika adalah rangkaian prinsip-prinsip moral yang memisahkan hal yang baik dan juga hal buruk serta apa yang harus dilakukan dan juga apa yang tidak harus dilakukan oleh seseorang (Stead, Worrell, \& Stead, 1990). Sementara itu, menurut Satyanugraha (2003), etika merupakan ragam nilai dan norma yag dianut oleh suatu masyarakat, karena itu etika sendiri diarikan sebagai moralitas. Hal tersebut kemudian sejajar lurus dengan pendapat yang dikemukakan Boynton \& Kell (1996) mendefinisikan etika sebagai sebuah tatanan nilai yang terdiri dari kumpulan prisip moral dan juga standar yang berfokus pada tindakan manusiawi untuk dapat menentukan apa yang dianggap benar dan apa yang dianggap salah. Begitu juga dengan Arens \& Loebbecke (1980) yang mengatakan bawa etika terikat dengan perangkat moral dan juga nilai. Etika sendiri dianggap sebagai prisip moral dan perilaku yang kemudian dinilai sebagai sebuah perbuatan yang mulia sehingga menaikkan nilai kehormatan dan derajat martabat seseorang (Munawir, 1997).

AAOIFI (Accounting and Auditing Organization for Islamic Financial Institution), adalah sebuah organisasi yang menaungi Akuntan yang berpraktek di bidang Bisnis Syariah. Pravitasari (2015) menyatakan bahwa AAOIFI menetapkan Etika Profesi Akuntan Publik yang berpraktek di industri syariah dalam 6 point, yaitu Trustworthiness (kepercayaan), dimana akuntan diharuskan untuk jujur sehingga dapat dipercaya dalam menjalankan pekerjaannya; Legitimacy (keabsahan), dimana akuntan harus menjamin authenticity mengenai berbagai hal yang terkait dengan pelaksanaan pekerjaannya sesuai dengan aturan dan juga prinsip-prinsip syariah yang berlaku; Objectivity (objektivitas), akuntan harus independen, tidak memihak siapapun, terbebas dari berbagai konflik kepetingan dalam fakta dan penampilan; Professional competence and diligent (kompetensi dan kegigihan), yaitu akuntan harus memiliki kompetensi sesuai dengan tugasnya dan terlatih dengan baik; Faith driven conduct (keteguhan iman), artinya akuntan haruslah berperilaku teguh berdasarkan nilai-nilai agama yang dianut; Professional conduct and technical standards (Perilaku profesional dan teknis), dimana akuntan harus mematuhi standar akuntansi dan auditing yang telah ditetapkan AAOIFI ketika menjalankan tugas dan pekerjaannya.

Penerapan etika profesi di kalangan negara-negara barat (terlebih di USA) lebih difokuskan untuk tujuan dan maksud senantiasa mendapatkan kepercayaan stakeholder dan juga publik, sehingga menjada reputasi dan kredibilitas profesi di tengah-tengah masyarakat. Berkaitan dengan hal tersebut, etika profesi akuntan yang dirumuskan oleh AICPA menerapkan prinsip nilainilai yang kemudian diterapkan untuk menjaga reputasi dan kredibilitas tersebut. AICPA (2014) dalam AICPA Code of Professional Conduct kemudian merumuskan beberapa hal yang diatur dalam bentuk prinsip dasar etika profesi akuntan, yaitu Responsibilities, dimana akuntan bertanggungjawab dalam menjalankan tugasnya; The Public Interest, dimana akuntan berfokus pada kelayakan guna kepentingan publik yaitu dengan bentuk menghargai kepercayaan yang berasal dari masyarakat; Integrity, dimana dalam menjalankan tugas profesionalnya akutan harus tetap jujur; Objectivity and Independent, dimana 
akuntan dalam menjalankan tugas profesionalnya harus tetap menjaga sikap obyektifitas, dan tidak terafiliasi dengan pihak manapun; Due care, dimana akuntan harus dapat memahami staandar-standar teknis yag berlaku dengan cara selalu menjaga dan meningkatkan kompetensi serta meningkatkan kualitas pelayanan yang diberikan; Scope and Nature of Services, dimana akuntan diharuskan untuk paham mengenai prinsip-prinsip serta kode etik profesi untuk menentukan ruang lingkup dan bentuk pelayanan yang diberikan kepada publik.

Bila kita lihat lebih mendalam, prinsip-prinsip yang disusun AICPA bagi Etika Profesi Akuntan mendapat banyak pengaruh dari nilai-nilai materialistik dan juga sekuler serta bebas seperti nilai-nilai yang berkembang di negaranegara barat pada umumnya. Nilai-nilai tersebut kemudian berdampak pada bentuk sikap, tindakan dan kebiasaan yang dilakukan masyarakat sehingga melekat dan menjadi nilai yang dianut dan diakui oleh masyarakat. Kebenaran sendiri kemudian diukur sesuai dengan besarnya dukungan yang diberikan masyarakat luas akan suatu hal. Hal tersebut kemudian menjadi tolok ukur bagi masyarakat untuk menilai dan menganggap suatu hal baik atau buruk sesuai dengan persetujuan dan dukungan masyarakat.

IAPI (Institut Akuntan Publik Indonesia) merupakan lembaga yang mewadahi kumpulan Akuntan Publik di Indonesia. IAPI sendiri merupakan organsisasi yang baru dibentuk dengan konsep sama seperti IAI (Ikatan Akuntan Indonesia) namun dalam kompatemen sektor publik. Kode Etik Profesi Akuntan Publik kemudian diterbitkan oleh IAPI yang kemudian dipakai sebagai etika dasar pada saat memberikan dasa dan pelayanan bagi Kantor Akuntan Publik pada 2019 dan berlaku efektif per 1 Juli 2019. Kode etik tersebut kemudian digunakan untuk menetapkan prinsip-prinsip dasar serta aturan etika profesi yang kemudian harus diterapkan oleh setiap individu didalam KAP dan atau jaringan $\mathrm{KAP}$, terlepas apakah mereka merupakan anggota IAPI maupun tidak.

IAPI kemudian menyusun Etika Profesi Akuntan Publik berdasarkan perkembangan dan iklim bisnis yang terjadi. Adanya hal ini kemudian menimbulkan harapan agar nantinya Profesi Akuntan Publik di Indonesia untuk meningkatkan kompetesi, daya saing, serta kualitasnya berdasarkan standar profesi dan kode etik yang berlaku dan diakui di dunia internasional. IAPI membagi Kode Etik Profesi Akuntan Publik menjadi dua bagian : dimana Bagian A berisikan prinsip dasar etika profesi yang bentuknya konseptual. Bagian B berisikan kerangka konseptual yang diterapkan pada situasi tertentu. Bagian A yang ada pada prinsip-prinsip dasar Etika Profesi Akuntan Publik menurut Komite Etika Profesi IAPI dalam Kode Etik Profesi Akuntan Publik (2019) terdiri dari Prinsip Integritas, yaitu dalam menjalin hubungan profesionalnya, akuntan harus bersikap jujur dan tegas; Prinsip Obyektifitas, yaitu dalam menimbang pengambilan keputusan profesionalnya, seorang akuntan harus bersikap obyektif dan tidak terafiliasi dengan pihak manapun sehingga mempengaruhi kesubyektifitasannya; Prinsip Kompetensi serta Sikap Cermat dan Hati-hati Profesional (Professional Competence and Due Care), yaitu dalam melaksanakan kegiatan dan aktifitas profesinya, setiap praktisi wajib memelihara kompetensinya dan pengetahuan terkait jasa yang diberikannya; Prinsip Kerahasiaan, sesuai dengan ketentuan dan perundang-undangan yang berlaku, 
setiap praktisi harus bisa menjaga kerahasiaan informasi yang didapatkan dengan atau tanpa persetujuan kliennya; Prinsip Perilaku Profesional, berdasarkan aturan dan perundang-undangan yang berlaku, setiap praktisi harus dan wajib untuk taat dan patuh.

Manusia selalu bersentuhan dengan kebudayaan. Oleh sebab itu, manusia dikatakan sebagai makhluk budaya. Tidak ada manusia dalam suatu masyarakat yang kemudian tidak memiliki budaya dan begitu pula sebaliknya. Budaya manusia yang diwujudkan melalui nilai-nilai telah mewarnai rangkaian aktivitas yang dilakukan. Nilai-nilai budaya berperan dalam menentukan cara berpikir dan berperilaku. Sehingga nilai-nilai ini sebetulnya yang hadir di balik perilaku manusia yang terungkap melalui ucapan, perbuatan dan materi (Koentjaraningrat, 2011). Kebudayaan meliputi suatu bidang yang sangat luas dan solah-olah tidak memiliki batas. Kata "kebudayaan" sendiri diambil dari bahasa Sansekerta yaitu buddhayah (buddhayah dalam bentuk jamak, sementara buddhi dalam bentuk tunggal) yang berarti budi atau akal. Budaya merupakan seperangkat nilai-nilai yang mendasari tindakan-tindakan, tujuan dan visi setiap (2017)individu yang berada dalam suatu kelompok masyarakat (Koentjaraningrat, 2011).

Masyarakat Indonesia merupakan masyarakat religius yang berkepercayaan dan keyakinan bahwa Tuhan Yang Maha Esa adalah pencipta dan pemilik kekuatan tertinggi di alam semesta. Manusia sendiri mempunyai posisi sebagai salah satu makhluk ciptaan Tuhan yang hidup dan diberikan kesempatan untuk memanfaatkan alam semesta untuk memperoleh kesejahteraan. Namun dalam dalam pemenuhan kesejahteraannya, manusia tidak boleh lupa untuk bersyukur atas segala rahmat Tuhan.

Budaya berfungsi sebagai pengikat seseorang dalam suatu masyarakat. Melalui kebudayaan yang melekat dalam dirinya, manusia juga dapat melakukan adaptasi dan mampu bertahan hidup, kebudayaan menjadikan manusia sebagai sosok yang memiliki keunikan dari sekian banyak jenis makhluk yang tercipta di muka bumi ini. Wujud konkret kebudayaan meliputi: Benda-benda fisik hasil karya manusia; Sistem sosial yang menggambarkan wujud tingkah laku manusia; Kebudayaan dalam wujud gagasan dan; Nilai-nilai budaya (Koentjaraningrat, 2011). Budaya manusia diwarnai oleh berbagai simbol yang tercermin melalui sistem sosial. Hal ini tentu saja terkait dengan struktur sosial yang beranjak dari keseluruhan pola pemikiran dan pola tindakan dalam suatu realitas kelompok sosial yang memiliki simbol yang berbeda dengan simbol-simbol yang dianut oleh kelompok masyarakat lainnya. Kebudayaan berada dalam lingkup dimana manusia dalam suatu kelompok masyarakat hidup dengan menjalani nailai-nilai yang menjaddi landasan pokok untuk berperilaku dalam lingkungan tempat ia berada. Budaya juga merupakan cara hidup manusia untuk menyelesaikan masalah yang ditemui dalam berkehidupan. Kebudayaan merupakan wadah yang digunakan oleh manusia untuk pemenuhan berbagai kebutuhan hidup. Selain itu, kebudayaan bukan hanya merupakan seni dalam suatu masyarakat guna memenuhi keperluan dasarnya untuk dapat bertahan hidup, namun juga dianggap sebagai kontribusi yang diberikan manusia kepada alam lingkungannya. 


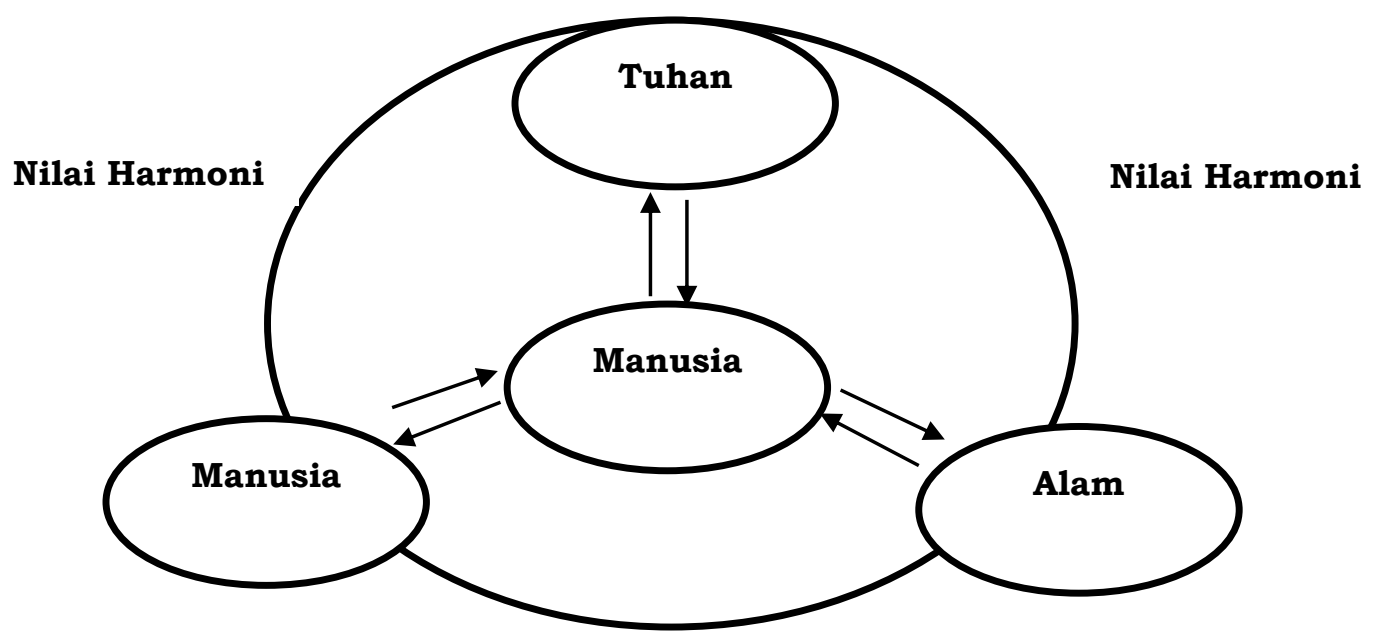

Gambar 1. Pendekatan Kebudayaan Tri Hita Karana

\section{Sumber : Suja, 2010}

Filosofis Tri Hita Karana merupakan kearifan lokal yang beranjak dari ajaran agama Hindu. Filosofi Tri Hita Karana menekankan bahwa kemakmuran, kesejahteraan, masyarakat yang adil dan kebahagiaan yang sejati dapat diwujudkan melalui tiga dimensi harmoni. Secara terminologis, Tri Hita Karana berasal dari bahasa Sansekerta yang merupakan rangkaian dari beberapa kata yaitu Tri, Hita, dan Karana yang memiliki makna tiga hal yang menjadi sebab lahirnya kesejahteraan dan juga kebahagiaan. Tri Hita Karana memiliki pengertian tiga hubungan harmonis. Ketiga unsur keharmonisan itu adalah Keharmonisan terhadap Brahmana (Tuhan Yang Maha Esa) sebagai pencipta alam semesta beserta isinya; Keharmonisan terhadap bhuwana atau alam semesta beserta segala isinya yang merupakan unsur kehidupan dan penghidupan manusia dan; Keharmonisan terhadap sesama manusia (Dweldo, 2009). Hal in berarti bahwa keharmonisan hidup manusia dapat diraih melalui tiga hal tersebut. Jika tidak, maka manusia akan semakin jauh dari kebahagiaan sejati bahkan akan mengalami kesengsaraan. Dalam hubungannya dengan Tri Hita Karana, Parahyangan (Ida Sang Hyang Widhi Wasa), Pawongan (manusia), Palemahan (alam tempat tinggal) adalah merupakan suatu kesatuan yang tidak dapat dipisahkan. Keterpaduan ketiga unsur Tri Hita Karana itu diproyeksikan dengan kelompok masyarakat memerlukan Palemahan dalam kehidupannya, sehingga boleh dikatakan manusia hidup di alam dan untuk alam sehingga terjadi suatu kesatuan antara masyarakat desa dengan wilayah yang ditempati (Budiantara, 2017).

Seperti yang telah diungkapkan sebelumnya, filosofis budaya Tri Hita Karana menekankan akan pentingnya menjalin keharmonisan diantara manusia dengan Tuhannya (parahyangan), manusia dengan manusia lainya (pawongan) dan antara manusia dengan lingkungan alam (palemahan). Pengimplementasia konsep Tri Hita Karana menekankan bahwa ketiga unsurnya harus diaplikasikan secara utuh dan terpadu (Budiasni, Atmadja, \& Herawati, 2015). Tiap- tiap unsurnya yaitu Parahayangan, Pawongan, dan Palemahan tidak ada yang menduduki porsi yang lebih istimewa. Mereka merupakan serangkaian yag seimbang dalam ucapan dan juga seimbang dalam tindakan. Tri Hita Karana dalam Hindu adalah sikap hidup yang berjalan seimbang dan harmoni antara 
percaya dan bhakti kepada Tuhan, mengabdi kepada sesama manusia, dan juga menyayangi alam berdasarkan yadnya (persembahan suci). Manusia membutuhkan Tri Hita Karana agar terlaksana karena keharmonisan dengan tiga dimensi sebagai perwujudan dari ini sari Veda, yaitu Satyam dan Sivam yang kekal abadi atau kebenaran dan kesucian tertinggi (Lestari, Windia, \& Astiti, 2015).

Dari Prinsip-prinsip etika profesi yang ada, dapat kita matrikkan berdasarkan nilai-nilai dalam Tri Hita Karana, maka akan didapat matrik sebagai berikut:

Tabel 1. Matrik Komparasi Etika Profesi berdasarkan aspek Nilai Tri Hita Karana

\begin{tabular}{|c|c|c|c|c|}
\hline $\begin{array}{ll}\text { Tri } & \text { Hita } \\
\text { Karana } & \end{array}$ & AAOIFI & AICPA & IAPI & \\
\hline $\begin{array}{l}\text { Keharmonisan } \\
\text { manusia } \\
\text { dengan Tuhan } \\
\text { (Parahyangan) }\end{array}$ & $\begin{array}{ll}\text { - } & \text { Trustworthiness. } \\
\text { - } & \text { Faith driven } \\
\text { conduct. }\end{array}$ & $\begin{array}{ll}\text { - } & \text { Responsibilities. } \\
\text { - Integrity. }\end{array}$ & - & $\begin{array}{l}\text { Prinsip } \\
\text { Integritas. }\end{array}$ \\
\hline $\begin{array}{l}\text { Keharmonisan } \\
\text { manusia } \\
\text { dengan } \\
\text { manusia } \\
(\text { Pawongan) }\end{array}$ & - Objectivity. & $\begin{array}{l}\text { - The Public } \\
\text { Interest. } \\
\text { - Objectivity and } \\
\text { Independent. }\end{array}$ & - & $\begin{array}{l}\text { Prinsip } \\
\text { Obyektifit } \\
\text { as. } \\
\text { Prinsip } \\
\text { Kerahasia } \\
\text { an. }\end{array}$ \\
\hline $\begin{array}{l}\text { Keharmonisan } \\
\text { manusia } \\
\text { dengan } \\
\text { lingkungan } \\
\text { alam } \\
\text { (Palemahan) }\end{array}$ & $\begin{array}{ll}\text { - } & \text { Legitimacy. } \\
\text { - } & \text { Professional } \\
\text { Competence and } \\
\text { dilligent. } \\
\text { Professional } \\
\text { conduct and } \\
\text { technical standards. }\end{array}$ & $\begin{array}{llr}\text { - } & \text { Due Care. } & \\
\text { - } & \text { Scope } & \text { and } \\
& \text { Nature } & \text { of } \\
& \text { Services. } & \end{array}$ & - & $\begin{array}{l}\text { Prinsip } \\
\text { Kompete } \\
\text { nsi serta } \\
\text { Sikap } \\
\text { Cermat \& } \\
\text { Hati-hati } \\
\text { Profesion } \\
\text { al. } \\
\text { Prinsip } \\
\text { Perilaku } \\
\text { Profesion } \\
\text { al }\end{array}$ \\
\hline
\end{tabular}

Sumber : Budiantara, 2017, Pravitasari, 2015, AICPA, 2014, IAPI 2019

Nilai etika profesi kemudian disandingkan dengan tujuan untuk dilakukan perbandingan untuk memudahkan pengelompokkan sesuai dengan nilai budaya yang ada pada Tri Hita Karana yang selanjutnya dapat dilihat bahwa nilai etika yang ada menunjukkan aspek-aspek Tri Hita Karana dalam membangun konsep Teori Etika Profesi. Ketiga Prinsip, yaitu AAOIFI, AICPA maupun IAPI memenuhi seluruh nilai aspek yang ada pada nilai budaya Tri Hita Karana.

Berdasarkan pengertian dan isi dari Tri Hita Karana diatas apabila dihubungkan dengan Etika Auditor yaitu pertama, hubungan manusia dengan Tuhannya. Parahyanga adalah hubungan harmonis antara manusia dengan Ida Sang Hyang Wida Wasa/ Brahmana sang pencipta/ Tuhan Yang Maha Esa. 
Dalam konsep teologi yang diyakini sebagai umat beragama, yang pertama harus dilakukan adalah bagaimana berusaha untuk berhubungan dengan Sang Pencipta melalui kerja keras sesuai dengan kompetensi yang dimiliki (Wiana, 2007). Manusia tidak dapat melakukan hal-hal yang tidak diperbolehkan oleh Tuhan seperti halnya melakukan kejahatan, kecurangan dan hal-hal lainnya yang tidak terpuji. Auditor haruslah tetap memegang teguh nilai spiritual dan juga selalu mengingat bahwa sega tindakan kejahatan akan dibalas oleh Tuhan Yang Maha Kuasa. Sementara itu hubungan manusia dengan Tuhan dalam praktik akuntansi yang dilakukan oleh Auditor, dapat diimplementasikan dengan tidak melakukan hal hal seperti manipulasi, korupsi dan kecurangan. Hal tersebut dapat diwujudkan bila auditor memegang teguh nilai integritas dalam dirinya dan juga merasa apapun yang dikerjakannya baik buruknya nantinya akan dipertanggungjawabkan hasilnya kepada Tuhan. Unsur-unsur spiritual merupakan sesuatu hal yang diperlukan oleh jiwa (Noviriani, Ludigdo, \& Baridwan, 2018). Adanya nilai spiritual yang dianut kemudian akan membangun keyakinan, kerinduan, cinta dan juga kasih saying yang nantinya akan mendorong seorang individu untuk selalu melakukan kebajikan dalam hidup. Dengan kata lain, adanya spiritual membuat manusia sadar akan adanya hubungan vertikal dan horizontal baik kepada sesama manusia maupun kepada Tuhannya. Ketika seorang individu telah sadar secara spiritual, individu dalam hal ini auditor, akan menyadari adanya amanat yang diberikan kepadanya sebagai makhluk Tuhan serta menjalankan perintah Tuhan di semua apek kehidupan.

Kedua, hubungan manusia dengan sesamanya artinya hubungan harmonis antara sesama manusia. Sebelum mempertanggunjawabkan hasil dan pekerjaannya, seorang auditor akan berhadapan dengan sesama manusia terlebih dahulu dalam hal ini klien. Pawongan dalam filosofi THK adalah manifestasi dari hubungan antar manusia. Pawongan berasal dari kata wong yang berarti manusia atau komunitas. Manusia sebagai makhluk sosial akan sangat bergantung pada orang lain dalam kehidupan mereka. Pawongan adalah hubungan harmonis antara sesama umat manusia. Dalam hal ini ditekankan agar sesama umat beragama untuk selalu mengadakan komunikasi dan hubungan yang harmonis melalui kegiatan Sima Krama Dharma Santhi / silahturahmi. Dan kegiatan ini dipandang penting dan strategis mengingat bahwa umat manusia selalu hidup berdampingan dan tidak bisa hidup sendirian. Oleh karena itu tali persahabatan dan persaudaraan harus tetap terjalin dengan baik (Wiana, 2007). Karena itu, manusia diharapkan menjalin hubungan harmonis dengan orang lain, sehingga akan ada ketenangan dan persik dalam kehidupan mereka. Ketika seorang auditor dapat memberikan performa kerja yang baik dengan berlandaskan etika profesi yang berlaku, hal tersebut akan memberikan kepuasan tersendiri baik bagi auditor maupun bagi klien. Hubungan dengan klien terjaga dengan baik karena adanya nilai objektivitas seperti pada etika AAOIFI maupun ICPA, dan IAPI. Sikap profesional tersebut juga sejalan dengan nilai public interest dalam Prinsip etika ICPA yang mana auditor bekerja melakukan pengungkapan dengan sebenar-benarnya sehingga adil dan transparan bagi kepentingan masyarakat banyak. Hal tersebut sesuai dengan penelitian Novriani, et al. (2018) yang menyatakan bahwa salah satu bentuk 
profesionalitas auditor merupakan bentuk kesadaran sosial. Selain auditor dituntut untuk berkomitmen pada profesinya, mereka juga harus fokus pada kompetensinya pada klien dan juga harus tetap menjalin hubungan dengan masyarakat. Selain itu auditor juga harus tetap memaintance lingkungan organisasi profesi contohnya Ikatan Akuntan Indonesia (IAI) untuk Akuntan maupun Ikatan Akuntan Publik Indonesia (IAPI) untuk akuntan Publik, dan sebagainya. Keharmonisan yang terjadi dilingkungan dapat diwujudkan dengan tetap bekerja sesuai prinsip dan nilai-nilai etis dan juga bekerja sesuai dengan standar profesi yang berlaku dalam hal ini berkelakuan profesional. Noviriani, et al. (2018) dalam penelitiannya mengatakan bahwa kesadaran profesi tercermin ketika auditor menyadari tugas pokok dan fungsi sebagai kewajiban yang harus ditaati.

Ketiga, hubungan manusia dengan alam lingkungan, artinya dalam palemahan. Palemahan berarti tanah, pekarangan atau lingkungan sekitar. Menurut Surpha (2004), implementasi palemahan ini adalah hubungan yang harmonis antara manusia dan alam dan lingkungan. Ini karena kehidupan manusia sangat tergantung pada alam dan lingkungan sekitarnya, sehingga mereka memiliki kewajiban untuk memelihara dan merawat alam dan lingkungan. Palemahan adalah hubungan harmonis antara umat manusia dengan alam lingkungannya. Ajaran ini menekankan kepada umat manusia untuk tetap menjaga kelestarian lingkungan alam sekitar, sehingga terwujud keharmonisan alam dan tetap terjaganya keseimbangan ekosistem (Wiana, 2007) - Auditor diharapkan mampu menjaga harmonisasi hubungannya dengan lingkungan. Pembangunan ekonomi yang pesat masa kini memicu munculnya sifat materialistis di tengah-tengah masyarakat memungkinkan memberi dampak negatif bagi lingkungan. Penerapan akuntansi modern cenderung memunculkan dampak yang kurang pro pada lingkungan baik alam maupun lingkungan profesi. Fakta menunjukka bahwa banyak terjadi skandal akuntansi dan juga manipulasi laporan keuangan yang melanda perusahaan (instansi maupun lembaga) serta rendahnya kepedulian akan tanggung jawab sosial dan juga lingkungan. (Munthe, 2018) dalam (Budiasni et al., 2019). Akuntansi sendiri merupakan awal dari terbentuknya suatu "kebijakan" yang diambil oleh suatu instansi atau perusahaan hendaknya memproklamirkan bahwa akuntansi adalah hasil kreasi manusia dan merupakan "agen" moral itu sendiri. Suryaningrum (2011) menyatakan bahwa saat ini berkembang akuntansi sosial secara kontemporer karena adanya kekhawatiran terhadap etika perusahaan, kekuasaan perusahaan, kekuatan perusahaan dan menurunnya ekologi lingkunga. Adanya nilai Palemahan ini kemudian akan melahirkan kecintaan terhadap pekerjaan, etos kerja yang tinggi, jiwa saling membantu, menghargai sesama sehingga melahirkan ligkungan yang harmonis di tempat kerja.

Perkembangan akuntansi baik secara global maupun lokal harus menyediakan bukti yang cukup bahwa akuntansi telah menjadi teknologi yang akhirnya membawa keberagaman dan keseragaman. Nilai budaya kemudian mungkin berkurang karena meningkatnya ketergantungan masyarakat dan pelaku akuntansi dengan teknologi. Hal tersebut mungkin saja mengurangi keterkaitan manusia dengan alam dan budaya. Sehingga akuntansi seharusnya dirancang untuk membawa kita untuk kembali tidak hanya ke nilai-nilai budaya. 


\section{SIMPULAN}

Pada hakikatnya, Tri Hita Karana memiliki pengertian tiga sebab lahirnya kesejahteraan bagi manusia yang sumbernya berasal daripada Keharmonisan Hubungan diantara Manusia dengan Tuhannya; Keharmonisan Hubungan diantara Manusia dengan Alam Lingkungannya; dan Keharmonisan Hubungan diantara Manusia dengan sesamanya. Praktik dan etika auditor bila dilihat pada nilai-nilai budaya Tri Hita Karana yang pertama yaitu hubungan manusia dengan Tuhannya dimana artinya sebagai pelaku profesi, auditor seharusnya tidak melakukan hal-hal yang bertentangan dan dilarang oleh Tuhan. Kedua, hubungan manusia dengan sesamanya artinya hubungan harmonis antara sesama manusia. Sebelum mempertanggunjawabkan hasil dan pekerjaannya kepada Tuhan, seorang auditor akan berhadapan dengan sesama manusia terlebih dahulu dalam hal ini klien. Ketika seorang auditor dapat memberikan performa kerja yang baik dengan berlandaskan etika profesi yang berlaku. Ketiga, hubungan manusia dengan alam lingkungan, artinya dalam palemahan, auditor diharapkan mampu menjaga harmonisasi hubungannya dengan lingkungan. Lingkungan dalam hal ini bisa dikatakan sebagai lingkungan alam da juga profesi seperti lingkungan kerja dan organisasi profesi sehingga tercipta keharmonisan dengan tetap bekerja sesuai prinsip dan nilai-nilai etis dan juga bekerja sesuai dengan standar profesi yang berlaku. Konsep akuntabilitas THK sebenarnya memiliki kontribusi besar bagi kesejahteraan masyarakat dan diyakini sebagai salah satu komponen penyusun utama tatanan sosial. Untuk itu, akuntansi yang digunakan sebagai media pertanggungjawaban adalah jembatan yang dibangun untuk meningkatkan kepercayaan dan penerimaan satu sama lain dalam organisasi atau organisasi dengan para pemangku kepentingannya. Konsep ini sejalan dengan yang diungkapkan oleh Patton (1992) dan Stanbury (2003) bahwa akuntabilitas nyata tidak hanya akuntabilitas keuangan formal, tetapi lebih dari itu, kemampuan untuk meningkatkan tanggung jawab organisasi terhadap lingkungan. Dengan demikian, penyelenggara desa adat Kuta memahami akuntabilitas THK ini sebagai bentuk pertanggungjawaban melalui penyediaan layanan publik atas kepercayaan yang telah diwajibkan sejauh ini. Kondisi ini sangat berbeda dari asumsi dasar teori modern (teori agensi, teori stakeholder, dan teori legitimasi) yang menjiwai tindakan individu dalam organisasi. Teori-teori modern ini umumnya bekerja dengan asumsi bahwa manusia adalah makhluk rasional bahwa setiap tindakan mencerminkan sifat oportunistik mereka dan bertindak berdasarkan kepentingan mereka sendiri. Ini akan sangat berpengaruh dalam pengembangan dan keberadaan suatu organisasi. Budaya merupakan unsur penting dalam membangun karakter dan sifat manusia. Perkembangan pemaknaan nilai-nilai budaya dan spiritualitas memungkinkan untuk menjalin hubungan melintasi perbedaan agama dan budaya, dan membuka kemungkinan timbulnya kerjasama dan usaha bersama untuk menghadirkan suasana lebih baik di masyarakat, memberdayakan sumber daya manusia, mencegah terjadinya kesenjangan antara ras, golongan tertentu atau individual yang lebih unggul terhadap yang lebih lemah, dan juga menggeser nilai yang ada sebelumnya bahwa uang ataupun kesuksesan yang bersifat material sebagai tujuan akhir dalam bekerja. Tanpa adanya nilai budaya 
dan spiritual yang dianut, seberapa besar perubahan eksternal yang terjadi, maka semuanya adalah sia-sia.

Bagi Pelaku profesi akuntasi terutama auditor agar dapat mengambil ajaran atau nilai positif yang ada pada budaya budaya yang mengajarkan kebaikan sehingga diharapkan dapat menerapkan kode etik dan profesi yang berlaku sejalan dengan nilai budaya yang dianut. Bagi masyarakat terutama Generasi Muda supaya selalu belajar dan mendalami kebudayaan serta menjaga hubungan baik dalam ajaran konsep Tri Hita Karana yang telah diwariskan oleh leluhur agar mendapatkan keseimbangan hidup yang lebih baik dan sejahtera dan masyarakat terus melestarikan nilai budaya sebagai upaya agar kearifan lokal masyarakat tetap terjaga dan terus dirasakan oleh generasi berikutnya. Peneliti selanjutnya diharapkan untuk mengguakan data yang lebih dalam serta melibatkan wawancara denga narasumber yang menguasai dengan baik keseluruhan mengenai konsep Kode Etik dan Profesi Akuntansi serta Nilai Budaya Tri Hita Karana. Penelitian berikutnya dapat menambahkan kode etik profesi akuntansi lainnya sehingga sekaligus dapat memberi wawasan bagi pembaca mengenai macam-macam kode etik profesi akuntansi dari lembaga lainnya. Selain itu juga penulis diharapkan untuk menggunakan lebih banyak referensi dan literatur dari dalam maupun luar negeri.

\section{REFERENSI}

American Institute of CPAs. (2014). AICPA - AICPA Code of Professional Conduct. Code of Professional Conduct and Bylaws Professional Standards, (June), $\quad 180 . \quad$ Retrieved from http://www.aicpa.org/Research/Standards/CodeofConduct/Pages /default.aspx

Antonius, B. (2011). Nurani Suku Buna Spiritual Capital dalam Pembangunan. Universitas Kristen Satya Wacana.

Arens, A. A., \& Loebbecke, J. K. (1980). Auditing, an Integrated Approach. PrenticeHall. Retrieved from https://books.google.co.id/books?id=8QJAQAAMAAJ

Bourdieu, P., \& Nice, R. (1980). The production of belief: contribution to an economy of symbolic goods. Media, Culture \& Society, 2(3), 261-293. https://doi.org/10.1177/016344378000200305

Boynton, W. C., \& Kell, W. G. (1996). Modern Auditing (6th ed.). New York: John Willey \& Sons, Inc.

Budiantara, I. K. D. (2017). Implementasi Ajaran Tri Hita Karana pada Masyarakat Hindu di Desa Sengkidu Kecamatan Manggis Kabupaten Karangasem. LAMPUHYANG Jurnal Ilmiah Pendidikan, Agama, Dan Kebudayaan, 8(2), 1-119. Retrieved from https://e-journal.stkipamlapura.ac.id/index.php/jurnallampuhyang/article/view/64/31

Budiasni, N. W. N., Atmadja, A. T., \& Herawati, N. T. (2015). Implementasi Corporate Social Responsibility berdasarkan Konsep Tri Hita Karana ( Studi Kasus Hotel Como Shambala Estate di Banjar Begawan Kecamatan. E-Jurnal Akuntansi Universitas Pendidikan Genesha, 3(1), 110. 
Budiasni, N. W. N., Ayuni, N. M. S., \& Trisnadewi, N. K. A. (2019). Implementasi Spiritual Capital Pengrajin Saab Mote: Telaah Dari Ajaran Agama Hindu ( Studi Pada Pengrajin Saab Mote di Desa Nagasepaha, Buleleng ). Internatioanal Journal of Social Science \& Business, 3(3), 4961.

Dweldo, I. . (2009). Sinergi Sistem Subak dengan Kelompok Tani di Desa Mopugat Utara Kecamatan Dumoga Utara Kabupaten Bolaang Mongondow Sulawesi Utara. Universitas Hindu Indonesia Denpasar.

Echols, J. M., \& Shadily, H. (1995). Kamus Inggris Indonesia. Jakarta: Gramedia Pustaka Utama.

Hp, N., \& Payamta. (2002). Sikap Akuntan Terhadap Advertensi Jasa Akuntan Publik. Jurnal Akuntansi, 6(1), 43-61.

IAPI. (2019). Kode Etik Profesi Akuntan Publik efektif per 1 Juli 2019. Jakarta: Institut Akuntan Publik Indonesia.

Khairi, M. S. (2013). Memahami Spiritual Capital dalam Organisasi Bisnis Melalui Perspektif Islam. Jurnal Akuntansi Multiparadigma JAMAL, $4(2), 165-329$.

Koentjaraningrat. (2011). Pengantar Antropologi I (Keempat). Jakarta: Rineka Cipta.

Lestari, P. F. K., Windia, W., \& Astiti, N. W. S. (2015). Penerapan Tri Hita Karana untuk Keberlanjutan Sistem Subak yang Menjadi Warisan Budaya Dunia: Kasus Subak Wangaya Betan, Kecamatan Penebel, Kabupaten Tabanan. Jurnal Manajemen Agribisnis, 3(1), 22-33.

Ludigdo, U., \& Kamayanti, A. (2012). Pancasila as Accountant Ethics Imperialism Liberator. Jurnal Akuntansi Multiparadigma JAMAL, 2(6), 159-168.

Munthe, A. S. P. (2018). Akuntansi Spiritual. Retrieved August 15, 2019, from https://scribd.com/doc/313546528/Akuntansi-Spiritual

Muslim, M. (2018). Varian-Varian Paradigma, Pendekatan, Metode, dan Jenis Penelitian dalam Ilmu Komunikasi. Media Bahasa, Sastra, Dan Budaya Wahana, 1(10).

Noviriani, E., Ludigdo, U., \& Baridwan, Z. (2018). Studi Fenomenologi atas Dilema Etis Auditor Internal Pemerintah. EKUITAS (Jurnal Ekonomi Dan Keuangan), 19(2), 217-240. https:// doi.org/10.24034/J25485024.Y2015.V19.I2.86

Patton, J. M. (1992). Accountability and Governmental Financial Reporting. Financial Accountability and Management, 8(3), 165-180. https://doi.org/10.1111/j.1468-0408.1992.tb00436.x

Pravitasari, D. (2015). Pemahaman Kode Etik Profesi Akuntan Islam Di Indonesia. An-Nisbah: Jurnal Ekonomi Syariah, 1(2). https:// doi.org/10.21274/an.2015.1.2.85-110

Rosyida, I. A. (2017). Perilaku Etis Dan Tidak Etis Oleh Akuntan Dalam Sebuah Organisasi. Ekonika, 2(1), 23-39. https://doi.org/10.1007/s10549-0143202-5

Saputra, K. A. K. (2012). Pengaruh Locus Of Control Terhadap Kinerja Dan Kepuasan Kerja Internal Auditor Dengan Kultur Lokal Tri Hita Sebagai Variabel Moderasi. Jurnal Akuntansi Multiparadigma, 3(1), 86100. 
Sarita, J. A. D. (2009). Pengaruh Gaya Kepemimpinan Situasional, Motivasi Kerja, Locus of Control Terhadap Kepuasan Kerja dan Prestasi. Jurnal Akuntansi Universitas Airlangga, 1-29.

Satyanugraha, H. (2003). Etika Bisnis: Prinsip dan Aplikasi. Jakarta: Lembaga Penerbit Fakultas Ekonomi Universitas Trisakti.

Stanbury, W. T. (2003). Accountability to Citizens in the Westminster Model of Government: More Myth Than Reality.

Stead, W. E., Worrell, D. L., \& Stead, J. G. (1990). An integrative model for understanding and managing ethical behavior in business organizations. Journal of Business Ethics, 9(3), 233-242. https:// doi.org/10.1007/BF00382649

Suja, I. (2010). Kearifan lokal sains asli bali. Surabaya: Penerbit Paramita.

Surpha, I. W. (2004). Eksistesi Desa Adat dan Desa Dinas di Bali. Denpasar: Pustaka Bali Post.

Suryaningrum, D. H. (2011). Sikap Sosio-Spritual Dalam Akuntansi Kontemporer: Telaah, Tantangan Dan Imajinasi Diri. AKRUAL: Jurnal Akuntansi, 3(1), 38. https://doi.org/10.26740/jaj.v3n1.p38-58

Triwuyono, I. (2012). Akuntansi Syariah: Perspektif, Metodologi, dan Teori. Jakarta: PT. Raja Grafindo Persada.

Wiana, I. K. (2007). Tri Hita Karana Menurut Konsep. Surabaya: Paramita.

Widiastuti, Eni \& Nugroho, M. A. (2015). Pengaruh Orientasi Etis, Equity Sensitivity, dan Budaya Jawa Terhadap Perilaku Etis Auditor pada Kantor Akuntan Publik di Yogyakarta. Jurnal Nominal, 119(3), 859867. 